\title{
EVALUATING THE FIT OF THE PARENT COMPANY WITH BUSINESSES TO DEVELOP CORPORATE STRATEGY (CASE STUDY: IKCO EMPLOYEES COOPERATIVE)
}

\author{
MOHAMMADALI SOBHANALLAHI \\ FARZANEH ASLIBEIGI \\ Technical-Engineering Faculty \\ Kharazmi University, Tehran, Iran \\ HOSSEIN RAHMANSERESHT \\ Business Management School \\ AllamehTabatabaie University, Tehran, Iran
}

\begin{abstract}
Deciding business portfolio, investment approach, and parenting management style need to understand how the fit of the parent company and its business, and the degree of potential of value creation by the parent. So, it is important to measure the fitness. This research which analysed factors affecting the characteristics of business and the parent company, offers a model to measure fitness. The proposed model has been implemented in a holding company and its results can be used to develop corporate strategy.
\end{abstract}

Keywords: Parent company, corporate strategy, value creation, parent company fit.

\section{Introduction}

The parent company as an organisation that stands between the business units and investors needs to justify its existence as an intermediary. It needs to have what Goold and Campbell called parenting advantage. In corporate strategy, the concept of parenting advantage has similar power to help develop corporate strategies (Goold, Campbell, \& Alexander, 1997).

As companies search for parenting advantage, they need to analyse and assess a number of inputs. They need to understand the strengths and weaknesses of the existing parent organisation: What are the current characteristics of the parent? They need to understand the nature of business currently owned by the parent: What are the parenting opportunities in these businesses?
These inputs do not provide direct answers for corporate strategy. Rather they provide understanding that is useful in the search of value creation insights. This search is an essentially creative process guided by the objective of parenting advantage: The strategist is searching for a strategy that will give the company parenting advantage (Goold et al., 1997). The outputs of this strategy development process are decision about which businesses to include in the portfolio and decisions about how the parent organisation should be designed. This process can help the "strategic architecture" that is used as a tool in order to decide which core competences to possess or develop (Hamel \& Prahalad, 1994). Meanwhile advances on strategic alignment of business need to related information systems (Kajalo, Rajala, \& Westerlund, 2007), so the fitness result can be 
used to design the information systems between parent and subsidiaries. Therefore, to achieve a systematic model to evaluate the fitness of the parent company with business, research is required and this paper identifies factors affecting fit and proposes a method for evaluating how to fit of the parent company and businesses.

\section{Review of Previous Studies}

Diversification in the 1960s-the concept of holding in different businesses and industries-was developed. However Rumlet (1986) from Harvard University, in a study of Fortune 500 companies, classified company businesses into single business, dominant business, related business, and conglomerate (unrelated) business categories and showed among these classes, related diversity creates better results than other classes (Rumlet, 1986).

In the $1980 \mathrm{~s}$, theorists such as Peters and Waterman in their book "In search of excellence" introduced the concept of "stick to the knitting" (Peters \& Waterman, 1982). This means staying with the businesses in which the knowledge, skills, understanding, and experience, can be focused. In the 1990s, Prahald and Hamel have developed the core competency concept (Prahalad \& Gary, 1990; Babaei Zaklily \& Mohammad Ali, 2004). Core competencies are capabilities that provide value to the customer and the customer will understand it.

The parenting decisions on business strategy was widely followed by Porter in research in 1987 (Porter, 1987; Goold \& Campbell, 1997; Collis \& Montgomery, 1998; Johnson \& Scholes, 2008 Ruefli \& Wiggins, 2003).

According to Porter (1987), and Johnson and Scholes (2008) one of the main reasons for the failure of many diverse companies is that they do not consider fitness and the parenting management styles in investment (Rahmanseresht \& Afshin, 2010).

Probably the most influential people to introduce parent management styles were Goold,
Campbell, and Alexander (1994). Their research led to the identification of management styles at the corporate level, and parenting advantage and parenting matrix were developed (Goold \& Campbell, 1987; Goold et al., 1994; Goold et al., 1997).

\section{Definitions and Concepts}

\section{Corporate Strategy and Value Creation}

A diversified company has two levels of strategy: business unit (or competitive) strategy and corporate (or company wide) strategy. Competitive strategy concerns how to create competitive advantage in each of the businesses in which a company competes. Corporate strategy concerns two different questions: what businesses the corporation should be in and how the corporate office should manage the array of business units. Corporate strategy is what makes the corporate whole, adding up to morethan the sum of its business unit parts (Porter, 1987). Parent companies affect value in four ways through stand-alone influence, linkage influence, central function and services, and corporate development activities. In each of these areas, it is possible for parent companies to create value. It is more common, however, for these areas of influence to result in value destruction (Goold et al., 1994).

\section{Parental Fit in Parenting Matrix}

The parenting matrix developed by Goold and Campbell introduces parental fit as an important criterion for including businesses in the portfolio. Businesses may be attractive in terms of the BCG or directional policy matrices, but if the parent cannot add value, then the parent ought to be cautious about acquiring or retaining them (Johnson \& Scholes, 2008).

There are two key dimensions of fit in the parenting matrix: 'Feel' the measure of the fit between each business unit's critical success factors and the capabilitie's (in terms of competences and resources) of the corporate 
parent, and 'Benefit' that measures the fit between the parenting opportunities, or needs, of business units and the capabilities of the parent (Johnson \& Scholes, 2008). The power of using these two dimensions of fit is as follows.

Figure 1 shows four kinds of business along these two dimensions of feel and benefit:

1. Heartland business units are ones which the parent understands well and can continue to add value to. They should be at the core of future strategy.

2. Ballast business units are ones the parent understands well but can do little for. They would probably be at least as successful as independent companies. If not divested, they should be spared as much corporate bureaucracy as possible.

3. Value trap business units are dangerous. They appear attractive because there are opportunities to add value (for instance, marketing could be improved), but they are deceptively attractive, because the parent's lack of feel will result in more harm than good (that is, the parent lacks the right marketing skills). The parent will need to acquire new capabilities if it is to be able to move value trap businesses into the heartland. It might be easier to divest to another corporate parent who could add value, and will pay well for the chance.

4. Alien business units are clear misfits. They offer little opportunity to add value and the parent does not understand them anyway. Exit is definitely the best strategy (Johnson \& Scholes, 2008).

This approach of considering corporate portfolios places the emphasis firmly on how the parent benefits the business units. It requires careful analysis of both parenting capabilities and business unit parenting needs (Johnson \& Scholes, 2008).

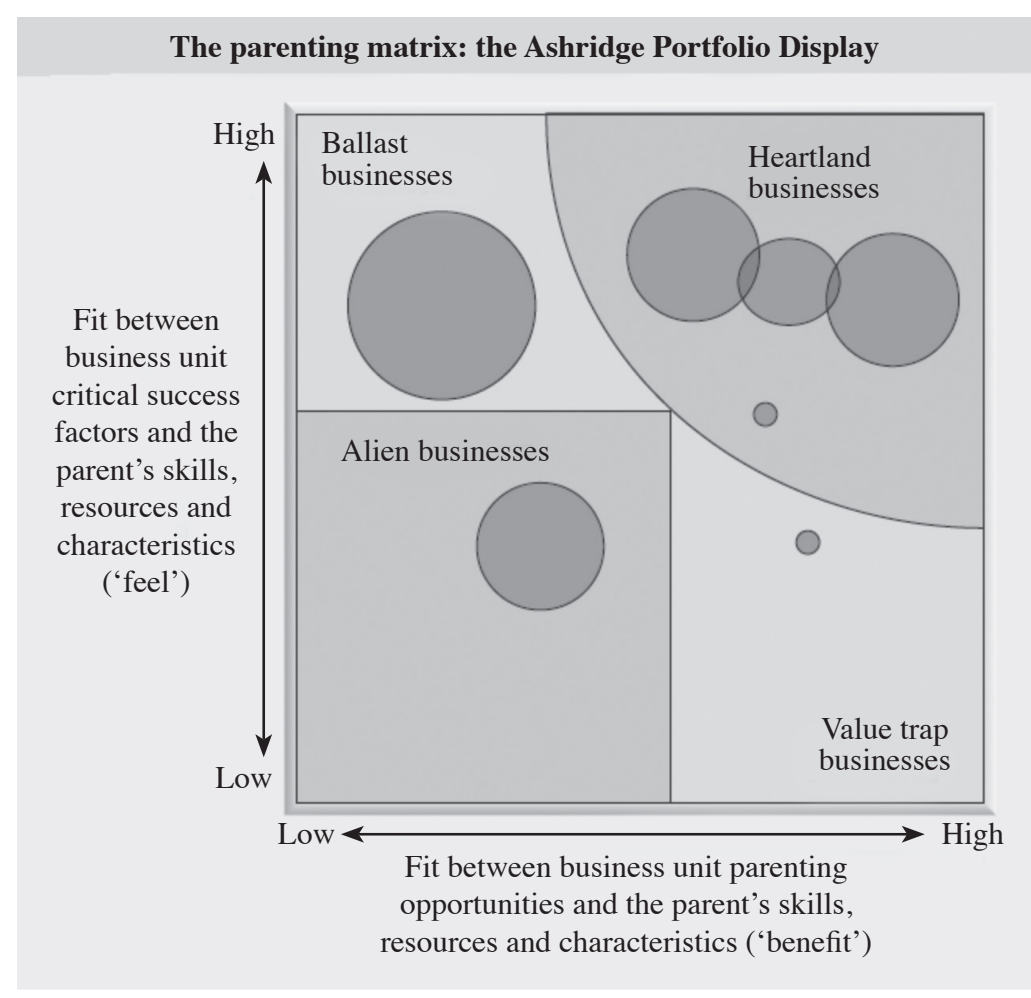

Figure 1. The Parenting Matrix by Johnson and Scholes (2008). 


\section{Parental Management Styles}

Goold et al. (1997), based on parenting influence through the planning and control aspects in business units, identified eight parental management styles. Three types were more common among them namely, strategic planning, strategic control, and financial control. Characteristics of each style are listed in Table 1.

Table 1

Parenting Management Styles

\begin{tabular}{llll}
\hline $\begin{array}{c}\text { Parenting } \\
\text { management } \\
\text { style }\end{array}$ & \multicolumn{1}{c}{ Strategic planning } & \multicolumn{1}{c}{ Strategic control } & Financial control \\
of distinctive & $\begin{array}{l}\text { Develop strategies based } \\
\text { on the synergy and } \\
\text { potential relationships } \\
\text { between businesses }\end{array}$ & $\begin{array}{l}\text { Coordination and review of } \\
\text { strategies, setting goals and } \\
\text { making appropriate financial } \\
\text { strategy and set strategic } \\
\text { relationship between } \\
\text { businesses }\end{array}$ & $\begin{array}{l}\text { Tight controls to } \\
\text { improve financial } \\
\text { parental role }\end{array}$ \\
Business role & $\begin{array}{l}\text { Focus on implemensiness } \\
\text { strategies }\end{array}$ & $\begin{array}{l}\text { Develop strategies in } \\
\text { coordination with the parent } \\
\text { company }\end{array}$ & $\begin{array}{l}\text { Business is } \\
\text { independent but should } \\
\text { adopt a strategy that } \\
\text { meets the company's } \\
\text { financial goals }\end{array}$ \\
Fit level of business & Diversity-related & The relative diversity & Unrelated diversity \\
\hline
\end{tabular}

Sources. Goold et al. (1994); Goold et al. (1997); Johnson \& Scholes (2008); Rahmanseresht \& Afshin (2010); Gottschalk (2007).

\section{Factors to Evaluate the Fit between Parent Company and its Subsidiary Companies}

Firstly, the strengths and weaknesses of the company's subsidiaries (the competitive business strength) and business opportunities and threats (industry attractiveness) are identified. Then the amount of feel and benefit of the parent company, according to parental characteristics, should be evaluated to estimate the fitness.

\section{The characteristics of the parent company}

According to Goold and Campbell, characteristics of the parent company are:
1. mental maps,

2. structures, systems, and processes.

3. function central services and resources.

4. people and skills, and

5. decentralisation contracts (Goold et al., 1994).

Based on these characteristics, a holding company with a philosophy of creating a unique insight to create value can be identified. In addition to parental characteristics, detailed analysis of the business is also an important part of the work. 


\section{Characteristics of business}

After the definitions and scope of each business are determined, two sets of characteristics can be analysed per unit: parental opportunities in business and key success factors of that business. Business characteristics can be identified from two perspectives namely from within the organisation and outside the organisation. The organisation's ability to conduct business and subsidiary performance is assessed internally and response to market opportunities and threats of the business is considered being external. Parenting opportunities can be derived from several sources; such as business may be defined as poor, lack of skills and resource, strategy unacceptable, and excessive overhead of such resources.

The analysis should focus on the key success factors likely, affected including the parent organisation. This analysis may lead to changes in the parent organisation or business. So, three types of fit test can be used.

1. Does presumption of parent organisations or opportunities for value creation match with business opportunities?

2. Does any of the parental characteristics, have efficiency for desired business opportunities?

3. How is the fit of key success factors and parental characteristics?

Understanding key success factors of the business model and evaluating them, can provide a clear picture of the subsidiary characteristics.

\section{Evaluating business based on SWOT}

The business model is the logic of how a company creates, presents, and describes business value. According to Osterwalder's model, the business model consists of essential components namely customer segments, the value proposition, channels, customer relationships, revenue streams, key resources, key activities, key partnerships, and cost structures (Osterwalder \& Pigneur, 2010).

\section{Business model components}

Customer Segments define the different groups of people or organisations an enterprise aims to reach and serve.

The Value Proposition describes the bundle of products and services that create value for a specific Customer Segment.

Channels describe how a company communicates with and reaches its Customer Segments to deliver a Value Proposition.

Customer Relationships describe the types of relationships a company establishes with specific Customer Segments.

Revenue Streams represent the cash a company generates from each Customer Segment (cost must be subtracted from revenue to create earnings).

Key Resources describe the most important assets required to make a business model work.

Key Activities describe the most important things a company must do to make its business model work.

Key Partnerships describe the network of suppliers and partners that make the business model work.

Cost Structure describes all costs incurred to operate a business model (Osterwalder \& Pigneur, 2010).

\section{Materials and Methods}

This study sought to provide a model for assessing the fit between parent company and its businesses. Using designed questionnaires and semi-structured interview survey, data were collected. The results of the implementation in one parent cooperative of Iran Khodro Industrial Group, is now reported in the following sections. 


\section{The Research Phases}

Three phases of the study, the research model, and a case study are described in the following:

1. Identify the essential factors in characteristics of parent company and businesses, and methods to measure them.

2. Analys parent opportunity to create value based on a. parental characteristics, and

b. key success factors of any businesses and analysis of SWOT (to identify strengths, weaknesses, threats, and opportunity).

3. Evaluate the fit through relationship between parenting opportunities to create value with business.

\section{Research Model}

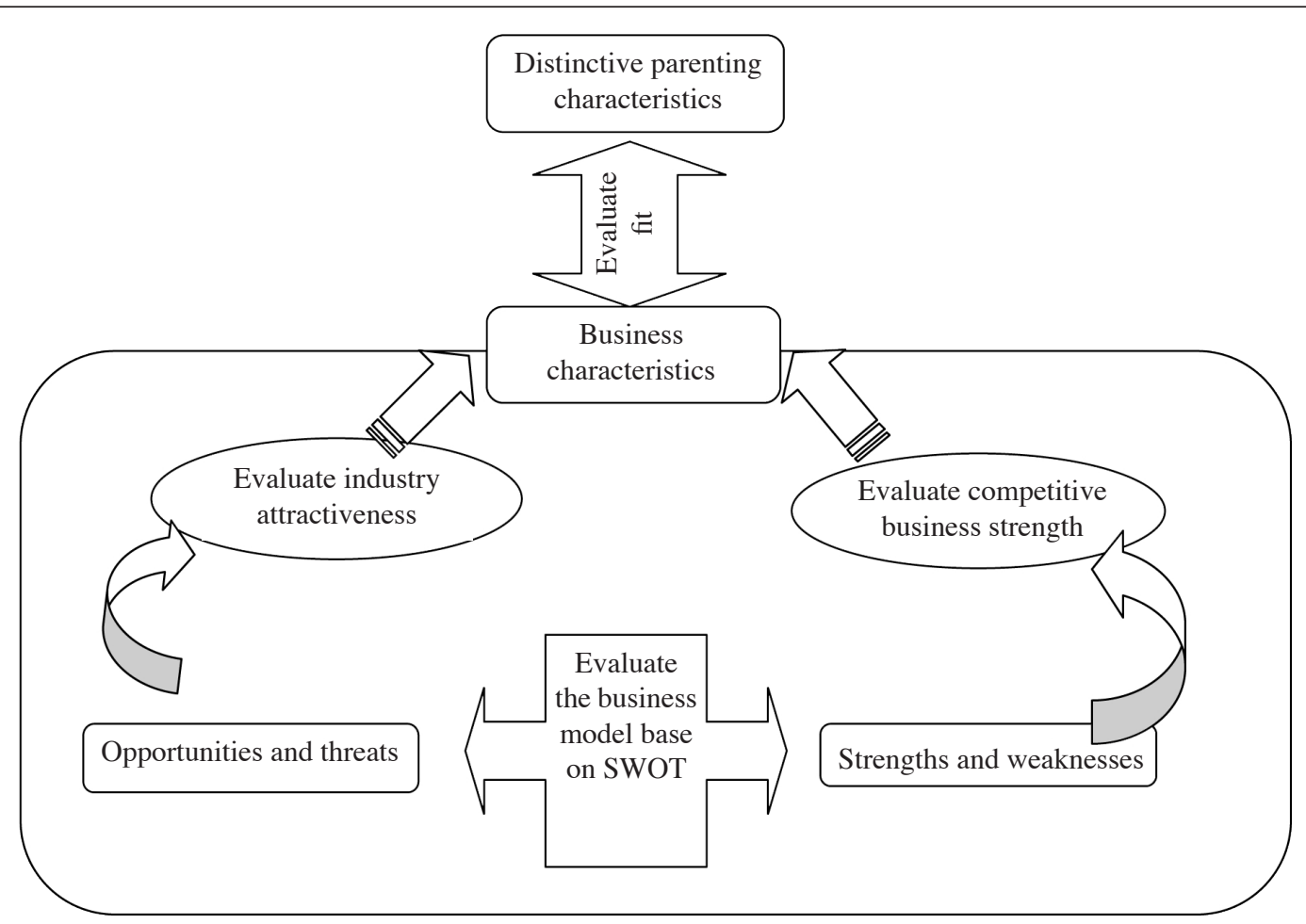

Figure 2. Research model

Table 2

Characteristics of the Parent Company

\begin{tabular}{ll}
\hline Characteristic & Measurement \\
\hline Mental maps & $\begin{array}{l}\text { Interviews with senior managers. Work experience of board } \\
\text { members. Strategic direction of the board of directors in the last } \\
\text { three years. Performance report in the past three years. }\end{array}$ \\
\hline
\end{tabular}




\begin{tabular}{ll}
\hline Characteristic & Measurement \\
\hline $\begin{array}{l}\text { Function central services and } \\
\text { resources }\end{array}$ & $\begin{array}{l}\text { Interviews with managers. Current structure, regulations, and } \\
\text { procedures in parent organisation. }\end{array}$ \\
$\begin{array}{l}\text { Decentralisation contracts } \\
\text { Interviews with managers about delegation and decentralisation } \\
\text { of the relationship }\end{array}$ \\
$\begin{array}{l}\text { Capabilities of personnel (based on skills, education, and work } \\
\text { experience) }\end{array}$ \\
Organisational structure and information systems.
\end{tabular}

\section{Measurements and Empirical Exploration Parenting characteristics}

Table 2 shows how each of the components of the parental characteristics was measured in the parent company.

\section{Business characteristics}

In order to evaluate the capabilities of competitive business and industry attractiveness, business model based on Table 3 was used to evaluate components. The business model based on SWOT analysis evaluates the strengths and weaknesses to assess competitive business and evaluates business opportunities and threats to assess the industry attractiveness.

Competitive businesses, industry attractiveness factors, and the key success factors of the business that were declared by expert of the parent company is presented in Appendix 1.

Table 3

Evaluation of the Components of a Business Model Based on SWOT

\begin{tabular}{cccc}
\hline Revenue / cost & Infrastructure & Customer \\
structure & $\begin{array}{c}\text { (key resource, key } \\
\text { partnership, key } \\
\text { activity) }\end{array}$ & $\begin{array}{c}\text { Value } \\
\text { proposition }\end{array}$ & $\begin{array}{c}\text { (segments, } \\
\text { channel, } \\
\text { relationship) }\end{array}$ \\
\hline
\end{tabular}

To measure these factors, a questionnaire was designed. This questionnaire determined the weight of each factor in Appendix 1 and evaluated the different parts of the business model components (infrastructure, the value proposition, customers and the revenue / cost structure) of various dimensions of industry attractiveness and competitive business by using a number of items (Appendix 2). Criteria and the items were provided by the parent company and 
business experts' views. Items were measured using a Likert scale and responses were given by senior managers in the businesses.

1. Population:

The population of the questionnaire was all managing directors of the company's businesses. The questionnaires were sent to 35 senior executives in 16 companies. A total of $75 \%$ return rate of the questionnaires was observed and the results were compared with the key performance indicators, data from 12 participants were used in this study.

2. Validity and reliability of questionnaire: The relationships described Appendix 2 , cover all components of the business model and key success factors which was confirmed by the expert team in parent company and business units.
To determine the reliability of the instrument Cronbach's alpha was used. Using SPSS software, Cronbach's alpha value of 0.819 was calculated, which is acceptable for this research.

\section{Determine the fit of the Parent Company for Value Creation in Business}

Parent company's potential value creation can be evaluated by the parent company's potential to solve weaknesses, preserve and promote the strengths, use opportunities, and neutralise threats. In an analytical process, the correspondence, between each of the weaknesses and threats in business and opportunities that a parent company has because of parenting characteristics, is formed. Parent company's potential help for value creation was determined through questionnaires and interviews. The form for analysis that is shown in Table 4, was completed for each business.

Table 4

The form of Analytical Process to Evaluate the Fit

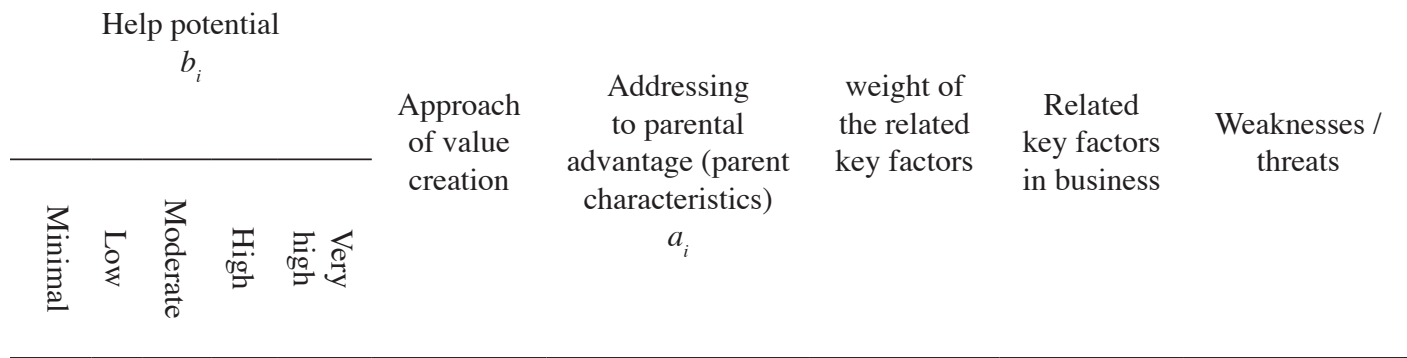

The first column group, parental help potential for each key success factor can be estimated as very high, moderate, low, and minimal. The fit score for parent company and each business was 
calculated using the following equation:

The fit score $=\sum_{i=1}^{n} a_{i} b_{i}$

\section{An Application}

\section{Measuring the fit of Parent Company and Businesses}

This study was carried out on a cooperative holding company to measure the identified characteristics and the fit of parent company and businesses. The senior management utility for management styles was evaluated to compare with the results of the proposed model. Table 5 shows the value creation opportunity in businesses because of parental characteristics.

After identifying business strengths, weaknesses, threats and opportunities and analyzing parental potential help to businesses in removing the weaknesses and threats, the degree of fit was determined by the parent company and the business in accordance with Table 6. For simplicity of implementation, the parent potential help for each value creation opportunity was considered equally.

Table 5

The Value Creation Opportunity Because of Parental Characteristics

Improvement of provision (such as helping to provide raw materials timely and with good quality and cost, assisting in facilitating recent legal permits, etc.)

Preparation and provision of technology, management, and development

Assistance in resolving the problems of business with external stakeholders, such as institutions and government agencies, raw material suppliers, and shareholders.

Assistance to business in certain circumstances such as liquidity crisis

Support finance investment projects, and risky and long-term projects

Infrastructure development (aid to development planning and control system - the establishment of a management information system, environmental studies, etc.)

Human resource development (helping to recruit, motivate, train, and develop managers and employees)

Assist key activities of value chain (such as the transfer of a number of experts to help the business in solving problems in product/service quality)

Central function and services

Help support value chain activities (such as helping to develop infrastructure, human resource development, and technology development subsidiary of the company) in comparison with competing holding

Transfer of skills and resources of a business to another business and facilitate the sharing of resources and expertise among them

Resolve conflicts and develop areas of cooperation between businesses in the prevention of intra-group competition (competition between affiliated companies)

Find internal and external partners to execute joint ventures

Corporate development activities 
Malaysian Management Journal Vol. 18, 23-38 (2014)

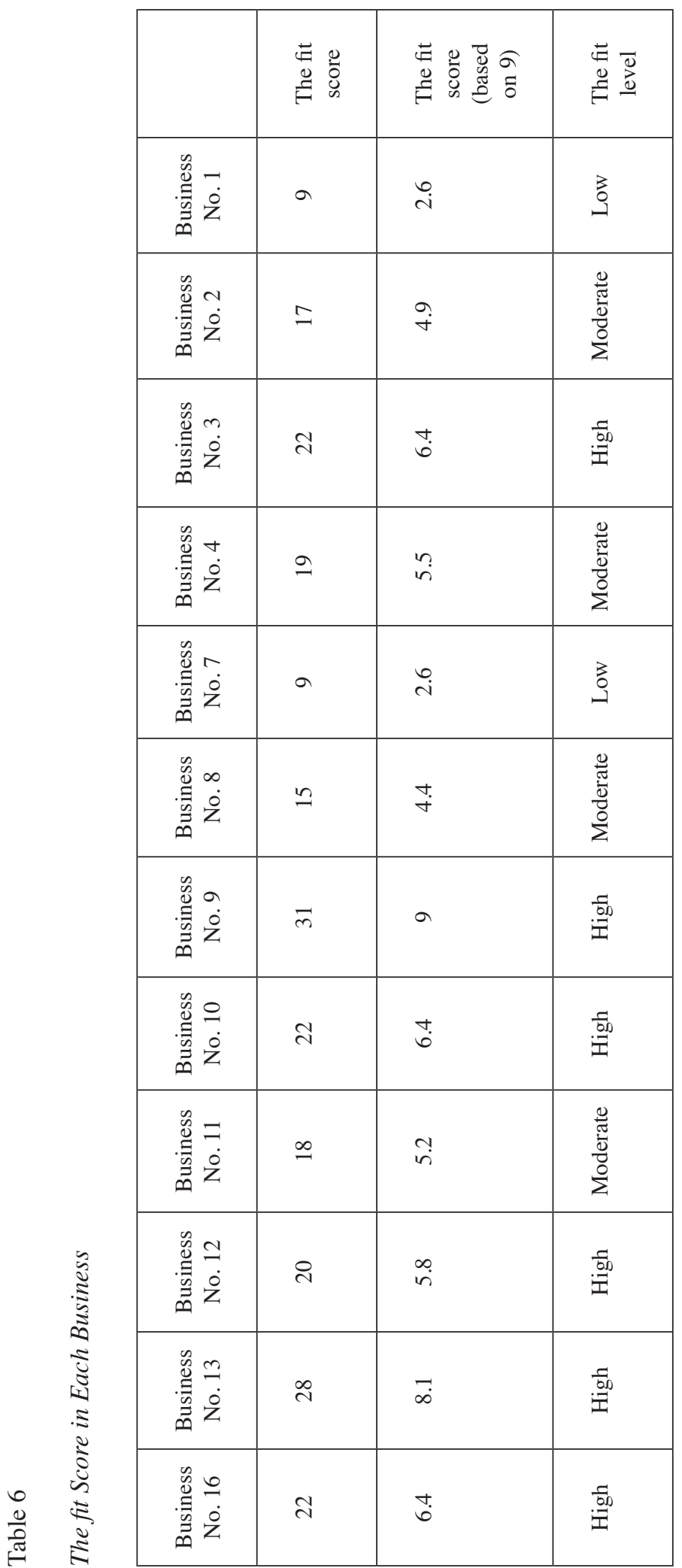




\section{Measuring Utility of Businesses and Parent Company's Experts}

In measuring the utility of business managers and experts about parenting influence in planning and controling aspects, strategic control management style was selected as the dominant mode. This result according to accepted fitness level for strategic control (Table 1), and result showed in Table 7 seem logical. A questionnaire was used to determine utility management style. The questionnaire was based on questionnaires by Goold and Campbell from Strategy Institute in London. The population of the questionnaire was 25 managing directors in business units and the parent company. The questionnaires were returned (65\% response rate), and the average was calculated for utility of parenting management style for nine participants (Figure 3).

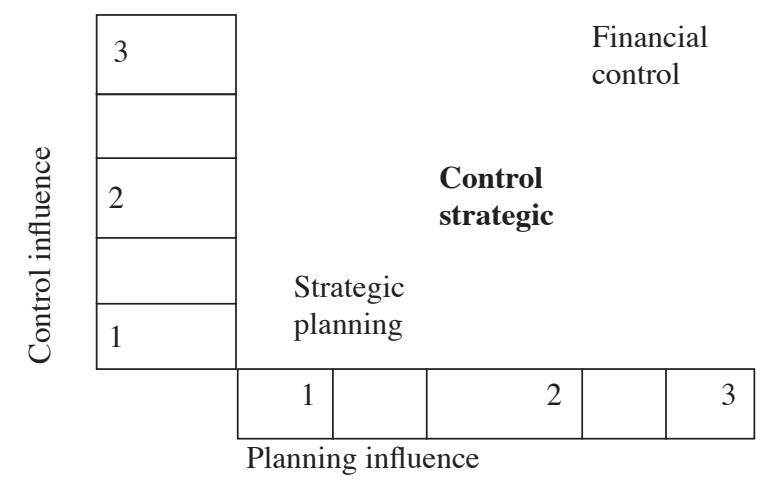

Figure 3. The manager's utility for parenting management style

\section{Conclusions}

Deciding on which business portfolio, investment approach, and parenting management style to choose, one needs to understand how the fit of the parent company and its business, influences the degree of potential of value creation by the parent. So, it is important to measure the fitness. This research analysed factors affecting the characteristics of business and the parent company, thus offering a model to measure fitness.
Proposed model has been implemented in a holding company and its results can be used to determine the corporate strategy of the company. The results showed that the proposed analytical model is compatible with the utility of managers regarding parenting management style. So, this model can be used to evaluate the fit of the parent company and business units. The suggested analytical model and the data analysis process provide ideas for better strategic architecture and planning of corporate strategy. 


\section{Appendix 1}

Key Factors Affecting Competitive Businesses and Industry Attractiveness

\begin{tabular}{|c|c|}
\hline Industry attractiveness & Competitive businesses \\
\hline Market growth rate & Ability of technological innovation in the production process \\
\hline Number of competitors & Ability to use different aspects of e-commerce for business \\
\hline The total risk of return of investment & $\begin{array}{l}\text { Product or service with lower costs (economic scale of } \\
\text { production) }\end{array}$ \\
\hline Entry barriers for new competitors & Product or service quality \\
\hline Variability of demand variables & Establishing appropriate distribution (wholesale and retail) \\
\hline Bargaining power of suppliers & $\begin{array}{l}\text { Techniques for rapid and accurate evaluating market and } \\
\text { customer segmentation }\end{array}$ \\
\hline $\begin{array}{l}\text { Impact of governmental laws and } \\
\text { regulations }\end{array}$ & Commercial and business skills \\
\hline $\begin{array}{l}\text { Opportunities for different products and } \\
\text { services }\end{array}$ & Properly advertise according to customer segmentation \\
\hline Market profitability & Factors related to human resources (skilled and efficient) \\
\hline \multirow[t]{10}{*}{ Fluctuating prices } & Factors related to financial resources \\
\hline & Ability to rapidly respond to changing market conditions \\
\hline & Experience in business management \\
\hline & Good brand image among customers \\
\hline & $\begin{array}{l}\text { Factors associated with key partnerships with suppliers, } \\
\text { contractors, etc. }\end{array}$ \\
\hline & Access to raw materials and services needed \\
\hline & Market share in business \\
\hline & Margins related to business \\
\hline & Customer service \\
\hline & Communication with customers \\
\hline
\end{tabular}




\section{Appendix 2}

Item Measure to Determine Competitive Business and Industry Attractiveness

\begin{tabular}{|c|c|c|}
\hline $\begin{array}{l}\text { Systems and procedures to support the adoption } \\
\text { of new ideas for innovation and value creation }\end{array}$ & $\begin{array}{l}\text { Ability of technological innovation in the } \\
\text { production process }\end{array}$ & \multirow{24}{*}{ 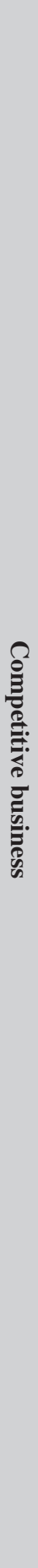 } \\
\hline $\begin{array}{l}\text { Management systems to support business value } \\
\text { defined }\end{array}$ & $\begin{array}{l}\text { Ability to use different aspects of } \\
\text { e-commerce for business }\end{array}$ & \\
\hline $\begin{array}{l}\text { Cost of services / products offered in comparison } \\
\text { with competitors }\end{array}$ & \multirow{2}{*}{$\begin{array}{l}\text { Product or service with lower costs } \\
\text { (economic scale of production) }\end{array}$} & \\
\hline Affordability of operating costs & & \\
\hline Key activities to be effective & \multirow{4}{*}{ Product quality or service provided } & \\
\hline $\begin{array}{l}\text { Introduce innovative approach and new models to } \\
\text { the market }\end{array}$ & & \\
\hline $\begin{array}{l}\text { Alignment of the business proposition customer } \\
\text { needs }\end{array}$ & & \\
\hline $\begin{array}{l}\text { Quality of products / services compared to other } \\
\text { competitors }\end{array}$ & & \\
\hline $\begin{array}{l}\text { Communication channel for the delivery and } \\
\text { distribution of products to customers }\end{array}$ & \multirow{2}{*}{$\begin{array}{l}\text { Establishing appropriate distribution } \\
\text { (wholesale and retail) }\end{array}$} & \\
\hline $\begin{array}{l}\text { Implementation of communication channels with } \\
\text { customer segmentation }\end{array}$ & & \\
\hline Customer segmentation & $\begin{array}{l}\text { Techniques for rapid and accurate evaluation } \\
\text { of market and customer segmentation }\end{array}$ & \\
\hline $\begin{array}{l}\text { Communication channels to promote products } \\
\text { services }\end{array}$ & Commercial and business skills & \\
\hline $\begin{array}{l}\text { Proper advertising according to customer } \\
\text { segmentation }\end{array}$ & $\begin{array}{l}\text { Proper advertising according to customer } \\
\text { segmentation }\end{array}$ & \\
\hline $\begin{array}{l}\text { Human resource with the expertise needed to } \\
\text { create business value proposition }\end{array}$ & \multirow{9}{*}{$\begin{array}{l}\text { Factors related to human resources (skilled } \\
\text { and efficient) }\end{array}$} & \\
\hline Clear vision of future business objectives & & \\
\hline High employee motivation and satisfaction & & \\
\hline $\begin{array}{l}\text { Clear responsibilities in delivering value } \\
\text { proposition to customers }\end{array}$ & & \\
\hline $\begin{array}{l}\text { Belief in responding to the needs of customers } \\
\text { and their satisfaction }\end{array}$ & & \\
\hline Development of staff competencies & & \\
\hline Fair compensation for employees & & \\
\hline Employee loyalty & & \\
\hline Threatened loss experts & & \\
\hline Financial resource to create value proposition & \multirow{2}{*}{ Factors related to financial resources } & \\
\hline Sustainable revenue streams & & \\
\hline
\end{tabular}




\begin{tabular}{|c|c|c|}
\hline $\begin{array}{l}\text { The ability to rapidly respond to changing market } \\
\text { conditions effectively }\end{array}$ & $\begin{array}{l}\text { Ability to rapidly respond to changing } \\
\text { market conditions }\end{array}$ & \multirow{20}{*}{ 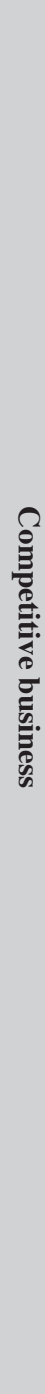 } \\
\hline $\begin{array}{l}\text { Adequacy of management procedures and } \\
\text { systems to provide a product or service }\end{array}$ & \multirow{4}{*}{ Experience in business management } & \\
\hline $\begin{array}{l}\text { Focus on opportunities rather than past successes } \\
\text { and future goals }\end{array}$ & & \\
\hline Proper management experience & & \\
\hline $\begin{array}{l}\text { Efficiency of service delivery processes and } \\
\text { product }\end{array}$ & & \\
\hline Customer loyalty & \multirow{2}{*}{$\begin{array}{l}\text { Good brand image among customers or the } \\
\text { public }\end{array}$} & \\
\hline Organisational image in the community & & \\
\hline Relations with key partners & \multirow{6}{*}{$\begin{array}{l}\text { Factors associated with key partnerships with } \\
\text { suppliers, contractors, etc. Access to raw } \\
\text { materials and services needed }\end{array}$} & \\
\hline Balance between outsourcing and internal jobs & & \\
\hline Threatened security of the resource market & & \\
\hline Threat of losing key partners & & \\
\hline Partners willing to cooperate with competitors & & \\
\hline $\begin{array}{l}\text { Commitment to a sustainable relationship based } \\
\text { on a win-win with key partners }\end{array}$ & & \\
\hline $\begin{array}{l}\text { Market share compared to the major competitors } \\
\text { in the market }\end{array}$ & Market share in the business & \\
\hline Margins compared to competitors & Margins related to business & \\
\hline Support services provided to the customer & Customer service & \\
\hline Rate of customers leaving & \multirow{4}{*}{ Communication with customers } & \\
\hline $\begin{array}{l}\text { Customers easy access to the communication } \\
\text { channel }\end{array}$ & & \\
\hline Quality of relations with customers & & \\
\hline $\begin{array}{l}\text { Threat of becoming irrelevant communication } \\
\text { channels with customers }\end{array}$ & & \\
\hline Threat of market saturation & \multirow{2}{*}{ Market growth rate } & \multirow{8}{*}{ 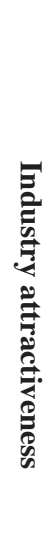 } \\
\hline Market growth in business & & \\
\hline $\begin{array}{l}\text { Threat of replacement products and services by } \\
\text { competitors }\end{array}$ & \multirow{2}{*}{ Number of competitors } & \\
\hline $\begin{array}{l}\text { Threatening competitors to obtain market share } \\
\text { current }\end{array}$ & & \\
\hline Risk of capital return in business & Total return of investment risk & \\
\hline Probability of imitation of the key activities & \multirow{3}{*}{ Entry barriers for new competitors } & \\
\hline $\begin{array}{l}\text { Barriers to entry into the market of products and } \\
\text { services for business }\end{array}$ & & \\
\hline Replacement cost for consumers & & \\
\hline
\end{tabular}




\begin{tabular}{|c|c|c|}
\hline Variations in the demand parameters of customers & \multirow{2}{*}{ Variability of demand variables } & \multirow{11}{*}{ 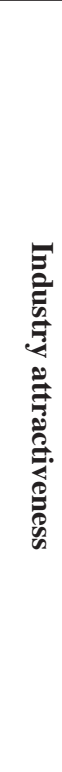 } \\
\hline Change in market demand & & \\
\hline Bargaining power of suppliers & Bargaining power of suppliers & \\
\hline $\begin{array}{l}\text { Impact of changes in governmental regulations on } \\
\text { business }\end{array}$ & Impact of governmental laws and regulations & \\
\hline $\begin{array}{l}\text { Opportunities for better quality of services and } \\
\text { products }\end{array}$ & \multirow{3}{*}{$\begin{array}{l}\text { Opportunities for different products and } \\
\text { services }\end{array}$} & \\
\hline Ability to assess customer needs more resources & & \\
\hline Opportunity to provide service to new customer & & \\
\hline $\begin{array}{l}\text { Margins threatened by competitors and } \\
\text { technology }\end{array}$ & \multirow{2}{*}{ Market profitability } & \\
\hline $\begin{array}{l}\text { Opportunity to create more revenue streams and } \\
\text { business models }\end{array}$ & & \\
\hline Threat growing faster than revenue expenditure & \multirow[t]{2}{*}{ Fluctuating prices } & \\
\hline Sustainable revenue streams & & \\
\hline
\end{tabular}




\section{References}

Babaei Zaklily, \& Mohammad Ali. (2004). Study the characteristics and performance of the holding company. Tehran: Iran.

Goold, M., \& Campbell, A. ( 1987). Strategic and styles. Oxford: Basil Blackwell.

Goold, M., Campbell, A., \& Alexander, M. (1994). Corporate level strategy. New York: John Wiley \& Sons.

Goold, M., Campbell, A., \& Alexander, M. (1997). Corporate strategy and parenting theory. Long Range Planning, 31(2), 308-314.

Hamel, G., \& Prahalad, C. K. (1994). Competing for the future. Boston MA: Harvard Business School Press.

Johnson, G., \& Scholes, K. (2008). Exploring corporate strategy (8th ed.). Pearson Education: Prentice Hall.

Kajalo, S., Rajala, R., \& Westerlund, M. (2007). Approaches to strategic alignment of business and information systems: A study on application service acquisitions. Journal of Systems and Information Technology, 9(2), 155-166.

Osterwalder, A., \& Pigneur, Y. (2010). Business model generation: A handbook for visionaries, game changers, and challengers. New Jersey: John Wiley \& Sons.

Gottschalk, P. (2007). CIO and corporate strategic management: Changing role of CIO to CEO. United States of America: Idea Group Publishing.

Peters, T. J., \& Waterman, R. H. (1982). In search of excellence. New York: Free Press.

Porter, M.(1987). From competitive advantage to corporate strategy (Vol. 59). Cambridge, MA: Harvard Business Review.

Prahalad, C. K., \& Hamel, G. (1990). The core competences of the corporation. Harvard Business Review, 68(3), 18.

Rahmanseresht, H., \& Afshin, F. (2010). Strategies and styles in holding companies. Tehran: Doran Publisher.

Ruefli, T. W., \& Wiggins, R. R. (2003). Industry corporate and segment effects and business performance: A non-parametric approach. Strategic Management Journal, 24(9), 861-879

Rumlet, R. P. (1986). Strategy, structure, and economic performance. Boston: HBS Press. 